Pavlov, P.M. (2021). Innovation policies in five leading countries in Latin America. Actual issues of management development. Proceedings of the International Scientific Conference on Management. Collection of Scientific Articles. European Scientific e-Journal, 8 (14), 33-52. Hlučín-Bobrovníky: “Anisiia Tomanek" OSVČ. (in Bulgarian)

Павлов, П.М. (2021). Иновационни политики в пет водещи Атржави в $\Lambda$ атинска Америка. Actual issues of management development. Proceedings of the International Scientific Conference on Management. Collection of Scientific Articles. European Scientific e-Journal, 8 (14), 33-52. Hlučín-Bobrovníky: “Anisiia Tomanek” OSVČ.

DOI: $10.47451 / \operatorname{man} 2021-08-001$

EOI: $10.11244 / \operatorname{man} 2021-08-001$

The paper is published in Crossref, Internet Archive, ICI Copernicus, Google Scholar, Academic Resource Index ResearchBib, JGate, ISI, CiteFactor, eLibrary databases.

\author{
Plamen Marinov Pavlov \\ chief assistant professor, $\mathrm{PhD}$ \\ Department of Industrial Business and Logistics \\ Faculty of Economics \\ University of Economics - Varna \\ Varna, Bulgaria \\ E-mail: pavlov@ue-varna.bg \\ ORCID: 0000-0003-4234-8016
}

\title{
Innovation policies in five leading countries in Latin America (in Bulgarian)
}

\section{Abstract:}

The importance of innovation for economic growth and for improving people's quality of life in recent years is palpable. In this regard, it is important to study the policies that countries implement to improve innovation activity. The aim of the article is to identify various levers, models and specific incentives for innovation and research and development (R\&D) in the five leading Latin American countries in this field and to draw conclusions and guidelines that are useful for both from a scientific point of view, as well as for the improvement of the innovation policy of Bulgaria. After studying the specifics, it was found that innovation policy plays an important role in the five countries studied. In some of them, such as Costa Rica and Colombia, good efficiency is achieved in the implementation of various measures in this area. But further and focused work on innovation and $R \& D$ is still needed to achieve satisfactory results.

Keywords:

innovation policy, innovations, stimulation of innovations.

\section{Пиамен Маринов Павиов}

ГА. ac. A-p

Катедра "Индустриален бизнес и могистика"

Стопански факултет

Икономически университет - Варна

Варна, Бъмгария 
JEL O380

\section{Иновационни политики в пет водещи Аържави в Аатинска Америка}

Резгоме:

Значението на иновациите за икономически растеж и за подобряване качеството на живот на хората през последните години е осезателно. В тази връзка е важно да се изследват и политиките, които Аържавите прилагат, за подобряване на иновационната активност. Целта на статията е Аа се установят разАични мостове, модели и конкретни стимули за иновации и научно-изследователска и развойна дейност (НИРА) в петте водещи в тази област страни от Аатинска Америка и да се направят изводи и насоки, които Аа са полезни както от научна гледна точка, така и за подобряване на иновационната политика на Бъцгария. СлеА изучаване на особеностите бе установено, че иновационната политика играе важна роля в изследваните пет държави. В някои от тях, като Коста Рика и Колумбия се постига Аобра ефективност при реализацията на различните мерки в тази област. Но е необходима още продъцжителна и целенасочена работа относно иновациите и НИРА, за Аа се постигнат задоволителни резултати.

Ключови думи:

иновационна политика, иновации, стимулиране на иновациите.

\section{Въведение}

В Анешния Аинамичен свят иновациите са от съществено значение за предприятията. В условията на глобализация и технологично развитие, потребителските нужАи се разнообразяват, жизненият цикъ $\Lambda$ на продуктите се съкращава, а конкурентната среда за фирмите става все по-тежка. Всяка компания трябова Аа се откроява, за Аа просъществува. Ситуацията е подоб̈на и на национално равнище - всяка страна, която претендира Аа бъде конкурентна, трябова да провежда адекватна политика за стимулиране на иновациите и свързаните с тях изследователски и развойни дейности.

Когато става дума за иновации обикновено се прави връзка с водещите световни икономики от Северна Америка, Европа и Източна Азия. Но трябва Аа се има предвиА, че всъщност във всички части на света се полагат усилия за стимулиране на иновационната дейност. В тази връзка, интерес представ яват и Аържавите, които имат значително по-ограничени финансови възможности, както и сериозни политически, икономически или социални проблеми, но 
които, въпреки трудностите, намират подходящите инструменти, за да провеждат национални иновационни политики. Нещо повече - в много страни с по-слаби икономики е постигната сравнително висока ефективност на прицаганите мерки. От Аруга страна, интересни изводи могат Аа се направят и от политиките в Аържави, които разходват огромни средства, но показват сравнително ниска ефективност в областта на иновациите.

Именно подобни примери могат да се открият в няколко Аатиноамерикански държави, които са водещи в областта на иновациите среА Аругите в региона. В тази връзка, научната цел в статията е ла се установят различните мостове, модели и конкретни стимули за иновации и научноизследователска и развойна дейност (НИРА) в петте водещи в тази област страни от Аатинска Америка, спореА Global Innovation Index 2020 [1] и Аа се направят изводи и насоки, които да са полезни както от научна гледна точка, така и за подобряване на иновационната политика на България. В разработката са използвани различни изследователски методи и подходи, в това число методите на анализ и синтез, на сравнение и на причинно-следствените връзки, както и системен и комплексен подходи.

\section{1. Същност на иновационната помитика}

Иновациите насърчават нарастването на производителността и конкурентните предимства на бизнеса (Australian Innovation System Report, 2017). Те са свързани както с големи печалби и пазарни успехи, така и с множество рискове, провали и фалити. В огромната част от случаите, за да има иновации е необходима подходяща социално-икономическа среда, Аобра научна база, благоприятна фискална политика и разбира се - предприемчиви иноватори. Всички тези условия могат да бъдат регулирани и направ явани от съвременната държава, с цел тяхното подобряване, посредством националната иновационна политика.

Националната иновационна политика е основна част на социалноикономическата политика на страната, която създава отношение на държавата към иновационната дейност, определя цели, насоки, формира органи на Аържавното управление в областта на науката, техниката, изследванията и реализирането на достигнатите резултати в тези дейности (Научнопроизводственный кластер Сибирский наукополис, 2020). Иновационната политика е изключително важен правителствен инструмент, насочен към увеличаване нивото на иновациите в конкретната национална или регионална икономика и към решаване на разАични социални и икономически проблеми, 
като ниски нива на производителност и ефективност или социалноикономически въпроси, свързани с енергията, околната среАа, зАравето и т.н.

За иновационната политика може да се каже, че тя е интерфейсът межАу политиката за научни изследвания и технологично развитие от една страна и индустриалната политика от Аруга и има за цел да създаде благоприятна рамка за представяне на идеи на пазара (European Parliament, 2021).

ЕАна съвременна иновационна политика предполага опиране върху много широка гама от Аейности, участници, институции, проблеми, обхващащи индустрията, банковото Аело, професионално-техническо обучение и т.н. и се стигне до техническа култура. Освен това, трябва да имаме предвиА, че всяка национална иновационна политика, следва да има за цел, обхващане на глобалните знания и технологии и тяхното аАаптиране и разпространение в местен контекст. Тоест, тя трябва да отчита националните особености, технологичните и икономически характеристики и възможности на конкретната страна.

Иновационната политика може да обхваща широк диапазон от мерки по икономическо регулиране, Аанъчно облагане, амортизационна политика, патентно-лицензионно и антитръстово законодателство, регулиране на пазара на технологии, стимулиране на Аребния и среден иновационен бизнес и привличане на средства за реализация на нововъведения. Но освен всички тези, по-скоро косвени мерки, иновационната политика може Аа си служи и с Аиректни плащания, нисколихвени или безлихвени кредити и субсидии за развитие на иновативни, високо-технологични или ключови за конкретната страна бизнеси, както и с конкретни държавни поръчки за доставяне на иновативни продукти, услуги или процеси. Може Аа обобщим, че тя най-общо е курс на действие, избор на цели и насоки, възприетата Аиния, съдържаща необходимите мероприятия и ресурси за постигане на целите и е свързана с елементите на вцастта и управцението.

Говорейки за иновационна политика, обикновено се обръща внимание и се дават примери с икономически силно развитите Аържави. Но тези, които разполагат със значително по-малко финансов ресурс или имат сериозни социални или политически проблеми, също могат да предложат полезни решения в тази област. Може би, защото те в много по-голяма степен трябва да разчитат на по-добра ефективност поради ограничените финанси. Именно в района на Аатинска Америка, особено среА водещите страни в областта на иновациите спореА GII 2020 - Чили, Мексико, Коста Рика, Бразилия и Колумбия, могат да се намерят подобни примери. 


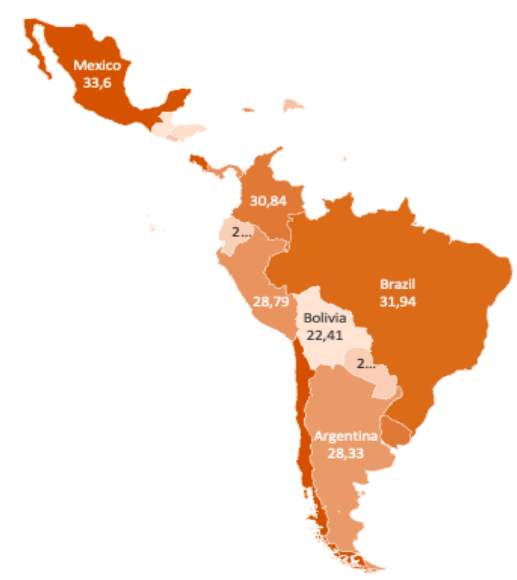

Фигура 1. Най-иновативните Аържави в Аатинска Америка според GII 2020 (Източник: Съставена от автора по данни от GII 2020)

Някои от тези Аържави, като Мексико и особено Бразилия, отАелят огромен финансов ресурс за реализиране на иновационната си политика и въпреки това резултатите не са много Аобри. От Аруга страна Чили, Колумбия и особено Коста Рика, разчитат преди всичко на по-добра ефективност при прилагане на конкретните мостове за стимулиране на иновационната дейност. Изследването на техните иновационни политики и различните конкретни механизми за стимулиране на иновациите и НИРА, може Аа се окажат интересни и полезни при изработване на бъдеща подобрена иновационна политика на България. В тази връзка ще бъдат изследвани конкретните иновационни политики във водещите пет страни спореА GII 2020 в Аатинска Америка, а именно Чили, Мексико, Коста Рика, Бразилия и Колумбия.

\section{2. Иновационна политика на Чими}

Чили е водещата Аьржава в областта на иновациите за Аатинска Америка. Според GII 2020, тя е на 54 място в света с индекс 33,86 (WIPO, 2020). През последните повече от 10 години, в страната се обръща много сериозно внимание на иновациите и политиките, способстващи нарастването на иновативността на чилийската икономика.

Основните органи, участващи в осьществяване на иновационната политика в Чили са Министерство на икономиката, развитието и туризма, Агенция CORFO, чрез InnovaChile, Национална агенция за изследвания и развитие (Agencia Nacional de Investigación у Desarrollo, 2021) и Националния съвет по иновации. 
ЕАин от важните Аокументи, направляващи изпълнението на иновационна политика в страната е Наука, технологии и иновации - нов пакт за развитие (Consejo Nacional de Ciencia, Tecnología, Conocimiento e Innovación para el Desarrollo, 2019).

ИзмежАу най-важните организации, ангажирани с финансирането на иновациите в Чили, е Иновационния фонА за конкурентоспособност и предприемачество (Dirección de Presupuestos, 2020), който е в структурата на Министерство на икономиката, развитието и туризма. За стимулиране на иновациите в Чили се прилагат различни програми, много от тях координирани от CORFO - Корпорация за насърчаване на производството. Такива са Програмата за капиталовложения, Програмата за приложни изследвания, Програмата за високотехнологични бизнес иновации. Стимулиране на иновациите може да се получи и чрез Научна инициатива Millennium (National Agency of Research and Development, 2020), която насърчава развитието на съвременни научни и технологични изследвания или Програма Technological Consortia 2.0, която се използва за създаване на нови технологични преАприятия.

В някои региони на Чили се използват и иновационни ваучери (Bonos Empresariales de Innovación, 2020), по подобие на много Аруги страни, за да подпомогнат МСП в техните усилия за реализиране на иновации, както и Аа улеснят връзката между предприемачи и научни учреждения.

В Чили работят и няколко технологични парка, които подпомагат иновациите и научните изследвания и закрепват връзката межАу наука и бизнес (Pacyt, 2021). Подобна роля, но с по-голям фокус върху предприемачеството имат и редица бизнес ускорители и бизнес инкубатори.

Освен това в страната има инициатива, която позволява да се ускори процеса за получаване на работна виза в рамките на максимален периол от 15 Ани (Invest Chile, 2021). Целта е Аа се улеснят местните и чуждестранни компании и организации, ориентирани към технологични ускуги и свързаните с тях сектори, Аа наемат персонал, който е необходим за насърчаване и разширяване на проектите им в Чили.

Много важен стимул, макар и непряк, за стимулиране на иновациите в Чили, са и данъчните облекчения. Те засягат корпоративния Аанък, като фирмите имат право да приспадат до 35\% текущи или капиталови разходи за НИРА или за придобиване на интелектуална собственост, но не повече от приблизително един милион евро (Invest Chile, 2021). 
Общите разходи за НИРА в Чили за 2016-2018 [2] година са средно 0,4\% от БВП (UNESCO, 2021). В реално изражение, това са межАу 850 Ао 870 милиона евро на година.

\section{3. Иновационна политика на Мексико}

Мексико, според GII 2020, е втората от страните в Аатинска Америка. Тя е на 55 място в света с индекс 33,60 (WIPO, 2020).

В Мексико Аейства Национален план за развитие 2019-2024 (Presidente de México, 2019). В частта Наука и технологии е посочено, че Федералното правителство трябва Аа насьрчава научни и технологични изследвания, Аа подкрепя студенти и академични работници със стипендии и Аруги стимули, в името на развитието на науката. Освен това Законът за науката и технологиите и Специалната програма за наука, технологии и иновации са в основата на подкрепата на иновационната дейност и научните разработки в Мексико.

Основният Аържавен орган, специализиран Аа формулира публичните политики на фелералното правителство и Аа насьрчава развитието на научните изследвания, технологичното развитие и иновациите с цел насърчаване на технологичната модернизация на страната, е Националният съвет за наука и технологии (El CONACYT, 2019). Бюджетните програми на CONACYT, предназначени за предоставяне на подкрепа за растеж и укрепване на науката, технологиите и иновациите, могат Аа бъдат класифицирани като: Секторни фондове, Смесени фондове, Институционални фондове, Фондове за институционална подкрепа, Финансова информация за фондовете на CONACYT, Програма за иновационни стимули, Фискален стимул за научни изследвания и технологично развитие.

Освен конкретните програми за подкрепа на иновациите и изследователската и развойна дейност, в Мексико действат и някои фискални стимули в тази област, като например Аанъчният кредит от 30 процента от АопъАнителните разходи, направени през финансовата година за научни изследвания или развитие на технологиите (Codigof, 2017). Ставката на Аанъчния кредит от $30 \%$ се прилага за Аопустими разходи за НИРА, наАвишаващи средните разходи за НИРА, направени през преАходните три години. (OECD, 2021). В случай на недостатъчно Аанъчно задъмжение, неизползваният Аанъчен кредит може Аа се пренася в продъцжение на 10 години, но стойността на предоставеното Аанъчно облекчение не може Аа надвишава 50 милиона мексикански песо. 
В Мексико има и алтернативни варианти за подпомагане на иновационната и предприемаческа дейност като множество бизнес инкубатори и наА 30 технологични парка (Research Centers and Technology Parks in Mexico, 2016).

Общите разходи за НИРА в Мексико за 2016-2018 година са межАу 0,4\% и 0,3\% от БВП (UNESCO, 2021). В реално изражение, това са межАу 3,585 и 3,041 мимиарда евро на година.

\section{4. Иновационна политика на Коста Рика}

Коста Рика е третата държава според GII 2020 в Аатинска Америка. Тя е на 56 място в света с индекс 33,51 (WIPO, 2020).

В страната Аейства Национален план за наука, технологии и иновации 2015-2021 (Plan Nacional de Ciencia, Tecnología e Innovación 2015-2021, 2015), който е един от основните документи в тази област в Коста Рика. Важно е Аа се обърне внимание, че в Коста Рика още от 1990 година действа и специален закон за Насърчаване на научното и технологично развитие и създаване на Министерство на науката, технологиите и телекомуникациите (Ley 우 7169 "Promoción Desarrollo Científico y Tecnológico y Creación de MICITT', 1990). Във връзка със закона, основен орган, регулиращ, организиращ и стимулиращ иновациите в страната е Министерството на науката, иновациите, технологиите и телекомуникациите. В страната през последните години Аействат наА 15 различни програми за стимулиране на иновациите, изследванията и разработките (Monge-González, 2018). Но най-важните от тях са Програмата за иновации и човешки капитал за конкурентоспособност и Програмата за подкрепа за малки и средни предприятия. Първата има за цел укрепване и развитие на производителността в икономиката чрез иновации в стратегически области от производствените сектори, както и чрез развитие на човешките ресурси (El Ministerio de Ciencia, Innovación, Tecnología y Telecomunicaciones, 2021). Втората - Програмата за подкрепа за малки и средни предприятия (PYMES Costa Rica, 2021), осигурява невъзстановима финансова подкрепа в максимален размер до осемдесет процента от общите разходи по различни проекти за иновации и технологично развитие. От нея могат Аа се възползват микро-, малки и среАни предприятия, които работят по проекти за технологично развитие, патенти за изобретения, проекти за трансфер на технологии, проекти за развитие на човешкия потенциал, проекти за технологични услуги. 
Коста Рика е единствената от петте анализирани Аържави, в която няма изрично преАлагани Аанъчни облекчения относно научноизследователска и развойна дейност или въвежАане на иновации. Но такива могат Аа се ползват, ако фирми или организации, занимаващи се с научни изслеАвания, са регистрирани в т.нар. зони за свободна тьрговия (Costa Rica, 2017).

Аруга възможност за подпомагане на иновационната дейност в страната са повече от 15 бизнес ускорители и бизнес паркове (PYMES Costa Rica, 2021) и особено няколкото технологични паркове, които подобряват сериозно връзката межАу научно-изследователска Аейност, иновации и реален бизнес.

Общите разходи за НИРА в Коста Рика за 2016-2018 година са межАу 0,5\% и $0,4 \%$ от БВП (UNESCO, 2021). В реално изражение, това са межАу 230 и 210 милиона евро на година.

\section{5. Иновационна политика на Бразимия}

Бразилия е четвъртата Аържава спореА GII 2020 в Аатинска Америка. Тя е на 62 място в света с индекс 31,94 (WIPO, 2020). В Бразилия Министерството на науката, технологиите, иновациите и сьобщенията (MCTIC) е отговорно за реализиране на иновационната политика на страната.

Бразилската иновационната политика се основава на серия от насоки, като стимулиране на бази от знания за иновации, разпространение на култура по отношение на иновации и предприемачество, гарантиране на насьрчаването на технологичното развитие, насърчаване на пазарите на бразилски продукти и услуги и подобряване на правните инструменти свързани с тях. Прилагат се конкретни мерки в тази насока, като разширяване на изследователската инфраструктура, опростяване на процеса на издаване на патенти, насърчаване на открити научни знания, предоставяне на дигитални платформи, стимулиране на създаването и развитието на стартыпи, оценяване на бразилските иноватори и разработчици и подпомагане увеличаването на частни инвестиции в научноизследователска и развойна дейност. Освен това, по отношение на иновациите в Бразилия от 2004 година действа и Закон за насърчаване на иновациите и научно-техническите изследвания (Presidência da República, 2005).

В Националния технологичен институт на Бразилия, към Министерството на науката, технологиите, иновациите и съобщенията, има Аве програми, които финансират иновациите и НИРА - PIBIC/PIBITI и РСІ (Instituto Nacional de Tecnologia, 2020). Освен това важно място при финансиране на иновациите в страната заема FINEP - правителствена 
структура, която има за цел стимулиране на икономическото и социалното развитие на Бразилия чрез публично насърчаване на науката, технологиите и иновациите в компании, университети, технологични институти и Аруги публични или частни институции. Програмите на FINEP Аействат в няколко направ ения - финансиране на фирми, които правят иновации посредством безлихвени или нисколихвени кредити, програми за рисков капитал и невъзстановима финансова подкрепа (Finep, 2021).

Важна роля по отношение на иновациите в Бразилия играят и технологичните паркове, седем от които са известни като Бразилска силиконова долина (Auditeste, 2020), както и множество бизнес инкубатори и бизнес ускорители (Cozer, 2019).

В Бразилия има и Аанъчни стимули за иновации и НИРА (Ministério da Ciência, Tecnologia e Inovações, 2019). Голяма част от тях са закрепени в самостоятелен закон, наречен Закон за доброто (Lei do bem). Стимулите, заложени в закона, се разпределят по компании или проекти със съответните Аанъчни облекчения, като например: ускорена амортизация на машини и оборудване, използвани за научни изследвания и разработки; допълнително изкцючване на процент от разходите за научноизследователска и развойна Аейност от базата за изчисление на печацба (Ао 60\%); 50\% намацение на Аанъци, такси и мита, наложени върху машини и оборудване, използвани за НИРА при придобиването им; 0\% процента Аанъци и такси, върху паричните преводи в чужбина за регистрация и подАържане на тьрговски марки, патенти и нови сортове растения и породи животни и други (Teixeira, C. et al., 2019).

Брутните вътрешни разходи за НИРА в Бразилия за периода 2016-2018 година са 1,3\% от БВП (UNESCO, 2021) или в парично изражение близо 20 милиарда евро годишно.

\section{6. Иновационна политика на Колумбия}

Колумбия е петата Аържава според GII 2020 в Аатинска Америка. Тя е на 68 място в света, с индекс 30,84 (WIPO, 2020).

Министерството на науката, технологиите и иновациите, с помощта на Министерството на националното образование, Министерството на информационните и комуникационни технологии и Министерството на търговията, индустрията и туризма, са отговорни за прилагане на политиката на страната в областта на иновационната и изследователската дейност. ЕАин от основните Аокументи, в които са закрепени важни цели и мерки по отношение на иновациите и НИРА в Колумбия е Национална политика по 
наука, технологии и иновации 2021-2030 (Conpes de Política de CTI, 2021). Тя има стратегически характер и цели да направи Колумбия еАна от трите водещи страни в Аатинска Америка по отношение на генерирането, използването и усвояването на научни и технологични знания.

В Колумбия действат редица конкретни програми за финансиране на иновационната Аейност (MINCIENCIAS, 2021). Освен на национално равнище, специално за столичния регион - Богота, също е приета и се изпълнява Публична политика на науката, технологиите и иновациите 20192038 (Alcaldía Mayor de Bogotá, 2019). В нея са заложени конкретни програми, вкцючително и в областта на иновациите, с регионално значение и с осигурено финансиране.

Освен пряката финансова подкрепа, в Колумбия има и редица облекчения, касаещи иновациите и НИРА (EY, 2021). Такива са отстьпки и Аанъчни облекчения, касаещи Аанъка върху Аоходите от инвестиции в научни изследвания, технологично развитие и иновации. Предлага се 25\% Аанъчна отстьпка плюс 100\% Аанъчно облекчение за инвестиции в научни, технологични и иновационни проекти, целящи да решават тьрговски проблеми, Аа генерират нови знания, да се възползват от нови пазарни възможности или да преодоляват проблеми с вътрешните процеси.

Аруго облекчение е освобождаване от $М$ С за внос в областта на научните изследвания, развитието и иновациите. Освобождаването от $\Lambda \mathcal{C}$ се прилага за оборудване, внесено от центрове за научни изследвания или технологично развитие и образователни институции, които са посветени на разработването на проекти, оценени като научни, технологични или иновативни. Аоходите, получени от развитието на научни, технологични и иновационни проекти, също могат да бъдат освободени от данък.

В Колумбия има и редица алтернативни варианти за подпомагане на иновационната Аейност като бизнес инкубатори, ускорители, специализирани платформи (Orientacion universia, 2020).

Брутните вътрешни разходи за НИРА в Колумбия за периода 2016-2018 година са межАу 0,3\% и 0,2\% от БВП (UNESCO, 2021) или в парично изражение межАу 800 и 560 милиона евро годишно.

\section{7. АопъАнитемни анамизи и изводи}

Анализирайки по-подробно тези пет водещи в областта на иновациите Аатиноамерикански Аържави, могат да се установят редица сходства. Във всички тях има разработени стратегически Аокументи в областта на 
иновационната политика, като се прави опит да се прицагат възможно найподходящи за конкретната страна подходи и стимули.

Във всички пет разгледани страни, основният двигател за изпълнение на иновационната политика са правителствата - директно чрез определени министерства или чрез конкретни държавни агенции.

И в петте водещи Аържави прякото финансиране на иновациите и НИРА играе важна роля, като се прилагат поне по няколко разАични програми в тази обиаст.

Аруга особеност в тези Аатиноамерикански страни е наличието на разнообразни непреки стимули за иновации или НИРА. В тази връзка, особено място имат Аанъчните облекчения. Аонякъде изключение прави Коста Рика, където те са налични само в зоните за свободна търговия.

Обща черта за всички водещи държави в Аатинска Америка в областта на стимулирането на иновационната дейност, е ролята на технологичните паркове, бизнес ускорителите и бизнес инкубаторите. Особено важни за иновациите са технологичните паркове, които обединяват силните страни на бизнеса, университетите и публичните власти, в това число и регионални, и създадат иновативна и технологична среда, която допринася положително за развитието не само на икономиката, но и на цялото общество.

Още няколко непреки стимули за иновации се прилагат в Чили, която е водещата държава в Аатинска Америка в тази област. Такива са иновационните ваучери и облекчената процедура за получаване на работна виза за висококвалифициран персонац. Ваучерите подпомагат засилването на връзката межАу университетски и Аруги научни и изследователски центрове от еАна страна и реалния бизнес от друга, а ускорената процедура за получаване на виза решава проблеми в действащи предприятия и организации, по отношение обезпечаване с подходящи кадри.

Интересни анализи могат да се направят и по отношение брутните вътрешни разходи за НИРА като процент от БВП (фиг. 2). 


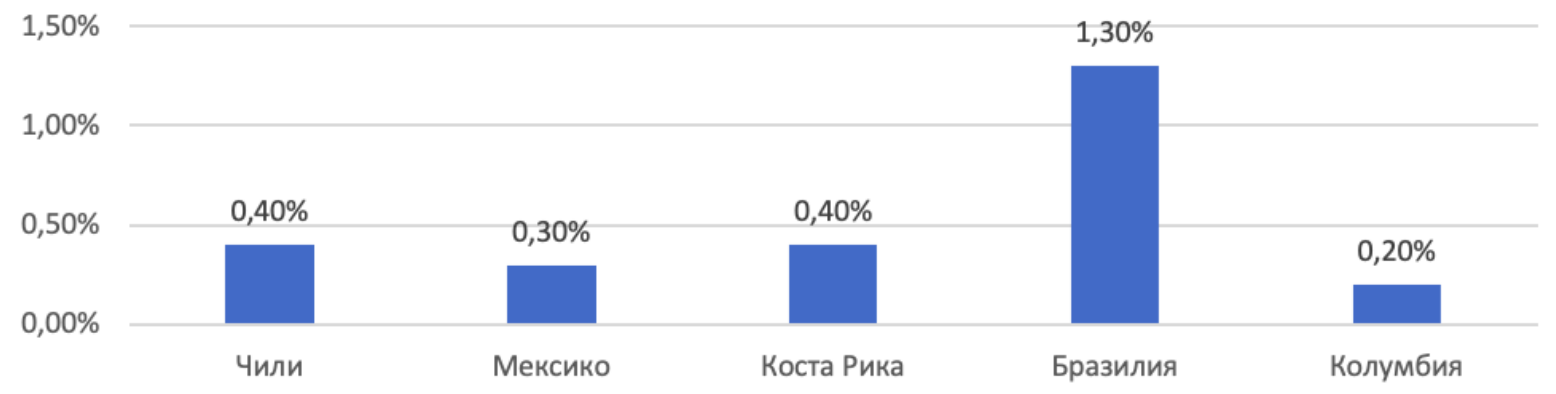

Фигура 2. Брутни вътрешни разходи за НИРА в Чили, Мексико, Коста Рика, Бразилия и Колумбия

(Източник: Съставена от автора по данни от UNESCO, 2021)

Тук Бразилия се представя значително по-добре с 1,3\%, но останалите четири Аържави са с 0,2-0,4\% брутни вътрешни разходи за НИРА. Това е много ниськ резултат, не само на фона на водещите иновативни страни в света, но Аори и спрямо по-ниско иновативни държави. За сравнение, в Израел и Република Корея, които са милери в тази област, тези разходи са наА 4,5\%, в Чехия 1,7\%, в Португалия 1,3\%, в Бъмгария 0,8\% и т.н. (UNESCO, 2021).

Аруга важна информация относно иновационните политики на петте водещи Аатиноамерикански страни според GII 2020 и разходваните от тях средства за стимулиране на иновационната и научно-изследователска дейност, може Аа се получи, ако се разгледат разходите от БВП за НИРА, падащи се на човек от населението. Този показател може да се определи като се отнесат разходите от БВП за НИРА към броя на населението на съответната държава (табл.1).

Таблица 1. Разходи от БВП за НИРА, разпределени на човек от населението

\begin{tabular}{|l|c|c|c|c|}
\hline \multicolumn{1}{|c|}{ Страна } & $\begin{array}{c}\text { Място в } \\
\text { GII2020 }\end{array}$ & $\begin{array}{c}\text { Разходи от БВП } \\
\text { за НИРА в } \\
\text { милиони Евро }\end{array}$ & Население & $\begin{array}{c}\text { Разходи от БВП за } \\
\text { НИРА на глава от } \\
\text { населението в Евро }\end{array}$ \\
\hline \multicolumn{1}{|c|}{ I } & II & III & IV & V=III/IV \\
\hline Чили & 54 & 870 & 19678363 & 44,2 \\
\hline Мексико & 55 & 3040 & 126014024 & 24,1 \\
\hline Коста Рика & 56 & 210 & 5163038 & 40,7 \\
\hline Бразилия & 62 & 20000 & 213521148 & 93,67 \\
\hline Колумбия & 68 & 560 & 51049498 & 11,0 \\
\hline
\end{tabular}

(Източник: Аанните за Разходи от БВП за НИРА са от UNESCO (2021)) 
И тук най-добри резултати Аемонстрира Бразилия, която по този показател се представя на нивото на страни като Аатвия, Кипър и Русия (UNESCO, 2021). Следват Чили и Коста Рика, които правят по-малко разходи от БВП за НИРА, на човек от населението, в сравнение дори с България и Румъния, които са Аържавите в ЕС с най-ниски разходи. И накрая са Мексико и Колумбия, които са по-близо до африканските страни, отколкото Ао водещите в света. Това, заедно с ниския процент брутни вътрешни разходи за НИРА, всъщност са Аве от важните причини, Аори водещите Аържави в Аатинска Америка, да са извън първите петдесет в света, в областта на иновациите. Но от Аруга гледна точка - ниските разходи за НИРА, като процент от БВП, както и скромните разходи от БВП за НИРА на човек от населението, които правят Колумбия, Мексико, Коста Рика и Чили, и в същото време постигнатите прилични резултати, защото тези държави все пак са среА водещите пет в региона, показват, че подбраните основни инструменти и мостове в иновационните им политики дават сравнително добри резултати.

От Аруга страна Бразилия, която заделя огромна сума за НИРА всяка година, не показва достатьчно Аобра ефективност и се намира Аалеч от водещите иновативни държави в света. Нещо повече, тя изостава и от няколко страни в региона като Чими, Мексико и Коста Рика, които разходват значително по-малко средства в тази област.

\section{8. Насоки за подобряване на иновационната политика на Бъмгария}

От всичко казано до тук, могат да бъдат изведени няколко насоки относно подобряване на иновационната политика на България.

Първо - не е достатъчно една страна да отделя огромни средства за иновации и НИРА, за Аа постига положителни резултати. Много по-важно е ефективното разходване на средствата. Това подсказва, че трябва да има предварително разработени и поставени конкретни цели за постигане чрез иновационната политика на страната и в същото време функционираща система за контрол по тяхното изпъцнение, както и навременна реакция при установяване на откцонения.

Второ - необходимо е да се подберат най-подходящите мерки в националната иновационна политика и да се намери правилното съотношение между преки и косвени стимули. Не бива да се подценява влиянието нито на Аиректното финансиране, нито на Аанъчните облекчения в областта на иновациите. Всички силно иновативни икономики в света, а също и водещите от региона на Аатинска Америка, прицагат комбинация от 
преки и косвени мерки за стимулиране на иновациите и НИРА. България е еАна от малкото европейски държави, които не прилагат Аанъчни облекчения нито по отношение на корпоративното, нито на подоходното облагане. По наше мнение е възможно да се въведат данъчни облекчения (включително и облекчаване на осигурителната тежест), свързани с подоходното облагане на високо-квацифициран персонац, зает с научно-изследователска и Аруга иновационна дейност, както в научните организации, така и в преАприятията от различните икономически сектори. Това би спомогнало не само за залържане на Аобрите висококвалифицирани калри в България, но и за привличане на такива от Аруги страни (особено от страни извън ЕС).

Трето - Необходимо е ла се усъвършенства законодателството в областта на публично-частните партньорства, за да се облекчат процедурите по създаване на технологични паркове, които са от изключителна важност за подобряване на средата за иновации. При условие, че в страната не се прилагат стимули от рода на иновационните ваучери, технологичните паркове биха подобрили значително взаимодействието между бизнес, научни организации, изследователски институции и регионални власти. Освен това с тяхна помощ ще се увеличат възможностите за иновации в най-важните и кАючови сектори и различни бизнеси на регионално ниво.

\section{Аискусия}

Иновациите са от изключителна важност, защото са способни да осигурят сериозни печалби за компаниите и по-голямо благосъстояние на обществото, но за да бъдат реализирани, се изискват и значително финансиране и създадена благоприятна среда. Именно конкретният начин на справяне с тези предварителни условия, обикновено води до разАичия в нивото на иновативност на различните страни.

Межлу иновационните политики на петте анализирани Аатиноамерикански държави се констатираха както редица сходства, така и разАичия в конкретните мерки и стимули, но при всички бе установено изпълнение на целенасочени политики в областта на иновациите и това е еАна от важните причини, точно те да са водещите в този регион от света.

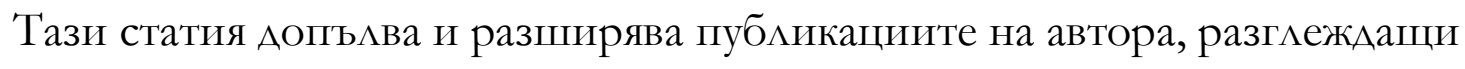
иновационните политики както на водещите наА петдесет Аържави в света в тази област, така и конкретно на най-иновативните страни от Африка.

Разработката може да бъде основа за по-нататышни анализи за Аоизясняване на слабостите и добрите резултати в разглежАаните държави от 
Аатинска Америка, както и за извеждане на още решения, свързани с подобряване на ефективността на мерките и стимулите, които се прицагат, с цел засилване на иновационната активност във фирмите и организациите.

Резултатите от този труд могат Аа бъдат полезни и при разписване или усъвършенстване на националната или регионалните политики в България, но така също и в Аруги страни.

\section{Закиючение}

В статията бяха изяснени различните мостове, модели и конкретни стимули за иновации и НИРА, в пет, водещи в тази област, Аържави от Аатинска Америка. Бе установено, че иновационната политика играе важна роля не само в най-силно развитите икономики, а и в почти всички страни в света. Петте анализирани държави от Аатинска Америка също прилагат разнообразие от мерки и стимули относно иновациите и НИРА. При това в някои от тях се постига и добра ефективност при реализацията на иновационните политики. Отчитайки особеностите на Аатиноамериканските Аържави и множеството проблеми за решаване, както икономически, така и социални, може да се обобщи, че Чими, Мексико, Коста Рика, Бразилия и Колумбия се справят по-добре със стимулирането на иновационната дейност от останалите в региона. Но въпреки това, те все още са изоставащи спрямо световните мидери и има сериозна необходимост от още продължителна и целенасочена работа в областта на иновациите и НИРА, за да се постигнат заловолителни резултати.

\section{Използвани източници:}

Agencia Nacional de Investigación y Desarrollo (2021). Retrieved July 20, 2021 from https://www.anid.cl/\#ciencia-e-innovacion

Alcaldía Mayor de Bogotá (2019). Política pública de ciencia, tecnología e innovación 2019-2038. Retrieved July 28, 2021 from http://www.desarrolloeconomico.gov.co/transparencia/planeacion/politicasy-lineamientos/politica-publica-ciencia-tecnologia-e-innovacion

Auditeste (2020). Parques tecnológicos no Brasil: conheça os principais! Retrieved August 8, 2021 from https://auditeste.com.br/parques-tecnologicos-no-brasilconheca-os-principais/

Australian Innovation System Report (2017), Chapter 4, pp. 56-60. Retrieved July 16, 2021 from 
https://publications.industry.gov.au/publications/australianinnovationsystem report2017/documents/ais-2017-chapter-4.pdf

Bonos Empresariales de Innovación (2020). Retrieved August 27, 2020 from https://www.bonosdeinnovacion.com/

Codigof (2017). Nuevo Programa de Estímulos Fiscales para impulsar la Investigación y Desarrollo de Tecnología en México y para México. Retrieved July 21, 2020 from https://codigof.mx/nuevo-programa-estimulos-fiscalesimpulsar-la-investigacion-desarrollo-tecnologia-en-mexico-mexico/

Conpes de Política de CTI (2020). Política Nacional De Ciencia, Tecnología e Innovación 2021-2030. Retrieved July 28, 2021 from https://minciencias.gov.co/sites/default/files/documento conpes ciencia te cnologia e innovacion.pdf

Consejo Nacional de Ciencia, Tecnología, Conocimiento e Innovación para el Desarrollo (2019). Ciencia, tecnología, conocimiento e innovación para Chile. Retrieved July 20, 2021 from https://www.cnid.cl/wpcontent/uploads/2019/12/CTCI-para-Chile-y-Contexto-para-lareflexion web.pdf

Costa Rica (2017). Free Trade Zone Regime. Retrieved July 27, 2021 from https://www.deik.org.tr/uploads/free-trade-zones.pdf

Cozer, C. (2019). Whow. Conheça as principais incubadoras e aceleradoras do Brasil. $\begin{array}{llll}\text { Retrieved } & \text { August } & \text { 9, } & \text { from }\end{array}$ https://www.whow.com.br/vendas/principais-incubadoras-e-aceleradorasdo-brasil/

Dirección de Presupuestos (2020). Ministerio de Hacienda. Fondo de Innovación para la Competitividad - Emprendimiento 2020. Retrieved July 20, 2021 from http://www.dipres.gob.cl/597/w3-multipropertyvalues-25190-25204.html

El CONACYT (2019). Retrieved July 20, 2021 from https://www.conacyt.gob.mx/Fondos-y-apoyos.html

El Ministerio de Ciencia, Innovación, Tecnología y Telecomunicaciones (2021). Retrieved July 23, 2021 from https://www.micit.go.cr/becas/programainnovacion-y-capital-humano-la-competitividad-pinn

European Parliament (2021). Fact Sheets on the European Union. Retrieved July 23, 2021 from https://www.europarl.europa.eu/factsheets/en/sheet/67/innovation-policy

EY (2021). Worldwide R\&D Incentives Reference Guide 2021. Retrieved July 27, 2021 from https://www.ey.com/en gl/tax-guides/worldwide-r-and-dincentives-reference-guide 
Finep (2021). Ações e Programas. Retrieved July 20, 2021 from http://www.finep.gov.br/a-finep-externo/sobre-a-finep

Instituto Nacional de Tecnologia (2020). PCI. Retrieved August 19, 2020 from https://www.int.gov.br/pci

Invest Chile (2021). Programas e inventivos. Retrieved July 20, 2021 from https://investchile.gob.cl/es/programs-and-incentives-for-investment/

Ley No 7169 "Promoción Desarrollo Científico y Tecnológico y Creación de MICITT (Ministerio de Ciencia, Tecnología y'Telecomunicaciones)" (1990). $\begin{array}{llll}\text { Retrieved July 23, } 2021 & \text { from }\end{array}$ https://micit.go.cr/sites/default/files/no $716900 . p d f$

Ministério da Ciência, Tecnologia, Inovação e Comunicações (2019). Política de inovação. p. 12. Retrieved July 20, 2021 from https://www.inova.rs.gov.br/upload/arquivos/202006/16182010-guia-deorientacao-para-elaboracao-da-politica-de-inovacao.pdf

MINCIENCIAS (2021). Programación de Oferta Institucional. Innovación y Productividad. Retrieved July 28, 2021 from https://minciencias.gov.co/oferta institucional/innovacion productividad

Monge-González, R. (2018). El espejismo de la política de innovación en Costa Rica. Research Gate. Retrieved July 27, 2021 from https://www.researchgate.net/publication/325858321 El espejismo de la politica de innovacion en Costa Rica

National Agency of Research and Development (2020) Millennium Science Initiative. Retrieved July 20, 2021 from https://www.iniciativamilenio.cl/en/home en/

Nauchno-proizvodstvennayy klaster Sibirskiy naukopolis (2020), Innovatsionnaya politika; Научно-производственный кластер Сибирский наукополис (2020), Инновационная политика. Retrieved July 27, 2021 from http://icnso.ru/innovation policy.html

OECD (2021). R\&D Tax Incentives: Mexico, 2020. Retrieved July 21, 2021 from https://www.oecd.org/sti/rd-tax-stats-mexico.pdf

Orientacion universia (2020). Startups en Colombia: ¿Qué instituciones privadas financian proyectos de innovación? Retrieved July 28, 2021 from https://orientacion.universia.net.co/infodetail/orientacion/consejos/startups -en-colombia-que-instituciones-privadas-financian-proyectos-de-innovacion7655.html

Pacyt (2021). Retrieved August 9, 2021 from https://www.pacyt.cl/el-parque/ 
Plan Nacional de Ciencia, Tecnología e Innovación 2015-2021 (2015). Retrieved July 23, 2021 from https://www.micit.go.cr/sites/default/files/pncti 20152021.pdf

Presidência da República (2005). Secretaria-General. Subchefia para Assuntos Jurídicos. LEI No 10.973, DE 2 DE DEZEMBRO DE 2004. Retrieved July 20, 2021 from http://www.planalto.gov.br/ccivil 03/ ato20042006/2004/lei/110.973.htm

Presidente de México (2019). Plan Nacional de Desarrollo 2019-2024. Retrieved July 20, 2021 from https://presidente.gob.mx/plan-nacional-de-desarrollo-20192024/

PYMES Costa Rica (2021). Fondo de innovación: PROPYME. Retrieved July 27, 2021 from https://www.pyme.go.cr/pymecr5.php?id=2

Research Centers and Technology Parks in Mexico (2016). Retrieved August 9, 2021 from https://sites.utexas.edu/cofafaculty/files/2018/04/Technology-Parksin-Mexico.pdf

Teixeira, C., Aliprandini, L., da Costa, G. (2019). Instituto Nacional de Tecnologia. Lei do Bem: incentivo à inovação tecnológica como forma de promover o aumento da competitividade do Brasil. Retrieved August 19, 2021 from https://www.int.gov.br/revista-inovativa-edicoes/n-29-outubro-a-novembroano-6-2019/2062-lei-do-bem-incentivo- $\%$ C3\%A0inova $\% \mathrm{C} 3 \% \mathrm{~A} 7 \% \mathrm{C} 3 \% \mathrm{~A} 3 \mathrm{o}$-tecnol $\% \mathrm{C} 3 \% \mathrm{~B} 3$ gica-como-forma-de-promover-Oaumento-da-competitividade-do-brasil

UNESCO (2021). Data for the Sustainable Development Goals. Retrieved July 20, 2021 from http://uis.unesco.org/en

Wikipedia (2021). List of countries and dependencies by population. Retrieved August 10, 2021 from https://en.wikipedia.org/wiki/List of countries and dependencies by pop ulation

WIPO (2020), Global innovation index 2020. Retrieved July 21, 2021 from https://www.wipo.int/global innovation index/en/2020/

\section{Коментар}

[1] Global innovation index предоставя подробни показатели за иновациите в 131 държави и икономики по света (за 2020 година). Той преАстав ява годишна класация на страните по техния капацитет и успех в областта на иновациите. Пубиликува се от Университета Корнел, INSEAD и Световната организация за интелектуална собственост, в партньорство с Аруги организации и институции 
и се основава както на субективни, така и на обективни Аанни, получени от няколко източника, вкАючително МежАународния съюз по телекомуникации, Световната банка и Световният икономически форум. Неговите 81 инАикатора изслелват широка визия относно иновациите, вкАючително политическата среда, образованието, инфраструктурата и сложността на бизнеса.

[2] Всички данни за разходите за НИРА на петте разглеждани страни са за периода 2016-2018 (последните налични в ЮНЕСКО) и са превърнати в евро с цел по-лесни сравнения. 